\title{
Prevalence of anemia in children from two rural schools at different altitudes. A transversal study
}

\section{Prevalencia de anemia en niños de dos escuelas rurales a diferentes altitudes. Un estudio transversal}

\author{
David Israel Garrido-Salazar, ${ }^{1}$ Santiago Moisés Garrido-Salazar, ${ }^{2}$ Thania Torres- Changoluisa, ${ }^{3}$ Michelle Fuseau- \\ Herrera, ${ }^{4}$ Christian Muyulema-Ruiz, ${ }^{5}$ Patricio Palate-Nuñez, ${ }^{1}$ Edgar Paul Toapanta, ${ }^{6}$ Miguel Gutiérrez-Tapia ${ }^{7}$
}

\begin{abstract}
ANTECEDENT: Anemia is a global public health problem, frequently occurring in children. However, no conclusive evidence is available regarding the influence of high altitudes on anemia in Andean children.

OBJECTIVE: To determine the prevalence of anemia in children from two rural schools, living at different geographical altitudes, but within the same administrative region.

MATERIAL AND METHODS: A transversal descriptive study was conducted between February and March 2017, through a secondary source, on children between the ages of 5 and 15 years. The patients were classified based on their residential location in Añaspamba and Lita, at 3300-3500 and 680-700 m above sea level, respectively. All the patients were subjected to a medical evaluation, including recording their anthropometric measurements and hemoglobin levels. Risk associations were also evaluated using the odds ratio.

RESULTS: The analysis included 228 patients. Anemia was identified in $27.67 \%$ and $11.59 \%$ children from Añaspamba and Lita, respectively. The risk association prevalent between anemia and residing at high altitudes was established (OR 2.92; $\mathrm{p}<0.01$ ); anemia risk in overweight children was also evident (OR 2.92; $\mathrm{p}<0.01)$.

CONCLUSION: The prevalence of anemia was greater in children from the rural community living at high altitudes. However, further studies are essential to clarify these risk associations.
\end{abstract}

KEY WORDS: Anemia; Child; High altitude; Rural population.

Resumen

ANTECEDENTE: La anemia es un problema global de salud pública que afecta frecuentemente a niños. Sin embargo, no hay evidencia conclusiva respecto de la influencia de la altitud en la anemia de los niños andinos.

OBJETIVO: Determinar la prevalencia de anemia en niños de dos escuelas rurales ubicadas a diferentes altitudes geográficas en la misma región administrativa.

MATERIALES Y MÉTODOS: Estudio transversal y descriptivo efectuado entre los meses de febrero a marzo de 2017, a través de una fuente secundaria, en pacientes de 5 a 15 años. Los grupos de estudio residían, respectivamente, en Añaspamba y Lita, a 33003500 y 680-700 metros sobre el nivel del mar, respectivamente. A todos los sujetos de estudio se les realizó evaluación médica: medidas antropométricas y concentraciones de hemoglobina. La asociación de riesgo se estableció con razón de momios.

RESULTADOS: Se analizaron 228 niños; en $27.6 \%$ se detectó anemia y en $11.6 \%$ en niños de Añaspamba y Lita, respectivamente. Se estableció la asociación de riesgo entre la prevalencia de anemia y residir en la altura (RM 2.92; $\mathrm{p}<0.01$ ); además, se evidenció el riesgo de anemia en niños con sobrepeso (RM 2.92; $\mathrm{p}<0.01$ ).

CONCLUSIÓN: La prevalencia de anemia fue mayor en los niños de la comunidad rural ubicada en las alturas. Para clarificar esta asociación de riesgo será indispensable aumentar el tamaño de muestra.

PALABRAS CLAVE: Anemia; niños; altura; población rural.
${ }^{1}$ Centro de Salud 1, Ministerio de Salud Pública del Ecuador, Ibarra, Ecuador. ${ }^{2}$ Centro de Salud San Antonio, Ministerio de Salud Pública del Ecuador, Santa Elena, Ecuador.

3 Prefectura de Imbabura, Ibarra, Ecuador.

${ }^{4}$ Servicio de Reumatología, Hospital de Especialidades de las FFAA 1, Quito, Ecuador.

${ }^{5}$ Facultad de Ciencias Médicas, Universidad Central del Ecuador, Quito, Ecuador.

${ }^{6}$ Dirección distrital 10D01, Ministerio de Salud Pública del Ecuador, Ibarra, Ecuador.

${ }^{7}$ Servicio de Pediatría, Hospital de Especialidades de las FFAA 1, Quito, Ecuador.

Recibido: 18 de agosto, 2017

Aceptado: 12 de diciembre, 2017

Correspondencia

David Israel Garrido Salazar

david_labinmuno@hotmail.com

Este artículo debe citarse como Garrido-Salazar DI, Garrido-Salazar SM, Torres-Changoluisa T, Fuseau-Herrera M, Muyulema-Ruiz C, Palate-Nuñez $P$, Paul-Toapanta E, Gutiérrez-Tapia M. Prevalencia de anemia en niños de dos escuelas rurales a diferentes altitudes. Un estudio transversal. Acta Pediatr Mex. 2018;39(4):289-298. 


\section{INTRODUCTION}

Anemia is a global public health problem usually linked to low nutritional iron intake. According to the World Health Organization (WHO) estimates, 2000 million people live with this condition, with a higher prevalence being noted in the limited-resources areas such as Latin America and the Caribbean. ${ }^{1}$ In the industrialized countries, the groups most susceptible to anemia are pregnant women (18\%) and preschoolers (17\%). Similarly, in developing countries, the groups most often affected are pregnant women (56\%), school-going children (53\%) and preschoolers (42\%). Under such circumstances, the children group is particularly sensitive to anemia, both in the developing countries and suburban parts of the developed countries. ${ }^{1,2}$ Iron deficiency in children is significantly associated with a disadvantage in three health conditions; psychosocial, economic and biomedical. Consequently, anemic children would expectedly exhibit poorer cognitive and academic achievements, as well as retarded physical growth compared with the non-anemic children. ${ }^{3}$ According to the Comprehensive Implementation Plan on Maternal, Infant, and Young Child Nutrition of the World Health Organization (WHO), mitigating iron deficiency anemia (IDA) is one of the main global health priorities. Therefore, governments of countries experiencing high prevalence of anemia need to start iron supplementation programs for children and pregnant women. ${ }^{4}$ In the Ecuadorian population, the iron intake could be below the required levels; this is an important factor considering that the degree of infant malnutrition is of prime concern. ${ }^{5}$ Besides, the Ecuadorian adolescent rural population subsists on a carbohydrate-rich diet, high in processed foods and fats, as the indigenous children have limited access to proper dietary intake. ${ }^{6}$ Therefore, identification of the population groups at a higher risk of developing anemia is crucial among the different ethnic communities, as such a step could facilitate the establishment of preventive risk-directed politics, with a more efficient use of the national economic resources. Determining the risk factors that affect an anemic patient is fundamental to providing specific treatment during the medical evaluation. ${ }^{6}$ Anemia also includes a variety of risk factors. However, no conclusive evidence is as yet available regarding the influence of residing at high altitudes (HA) on anemia in Andean children, although hemoglobin $(\mathrm{Hb})$ correction continues to be recommended based on the geographic residence. ${ }^{7,8}$ Besides, different variations could be observed in the adaptations associated with HA among the populations, as was noted in the comparison of the Tibetans with the Bolivian Aymara, as this latter ethnic group was more greatly affected by geographical differences. ${ }^{9}$ This fact is significant when the Ecuadorian population is studied, considering the similarity it bears with the rest of the Andean populations. Living at HA even for a short time periods is associated with an increased secretion of erythropoietin (EPO); $i^{10}$ however, the heightened rate of production of red blood cells (RBC) necessitates sufficient iron body storage. ${ }^{11}$ This is particularly crucial for the Latin American Andean population with its high prevalence of IDA, a disease condition that may be worsened by inhabiting $\mathrm{HA}$, which induces increased EPO levels, accompanied by ineffective erythropoiesis. ${ }^{12}$

The aim of this study was to present the frequency of anemia in two rural schools in Ecuador, as well as determine the possible association of $\mathrm{HA}$ dwelling with the risk of prevalence of anemia in the children of two rural communities in Ibarra, Ecuador. These findings could be of significance in charting the nutritional politics in the future, as well as during the medical anamnesis for general practitioners and pediatricians.

\section{MATERIALS AND METHODS}

An observational and transversal descriptive study was conducted in two rural communi- 
ties in Ibarra, Ecuador, from February to March 2017. The database was gathered by the mobile medical unit (MMU) of the Imbabura Prefecture (IP). Ibarra is an administrative region, situated in Imbabura province, approximately $116 \mathrm{~km}$ north of Quito. The rural communities including the population studied in this work are the Añaspamba and Lita. Añaspamba, east of Ibarra, is at a geographic altitude between 3300-3500 $\mathrm{m}$ above sea level (masl), supporting the ethnic groups which are mainly the Quechua and mestizos. The Lita are located in the north-west of Ibarra at 680-700 masl altitude, and show ethnic diversity among the Awás, Afro-Ecuadorians, and mestizos. The data were gathered during the provincial nutritional control campaign of the IP with the support of the Public Health Ministry of Ecuador (Ministerio de Salud Pública Del Ecuador, MSP).

From the review of the IP database, a total of 228 children, between 5 and 15 years of age were included. From a potential group of 267 patients, 39 children were excluded. The exclusion criteria included age outside the interval established for this work, lack of registered anthropometric parameters or absence of the $\mathrm{Hb}$ value. Patients possessing a recent diagnosis of infectious disease, any type of cancer, endocrine-metabolic, or any other chronic condition, which could affect the real appreciation of anthropometric measurements, were excluded. No sample size determination was done, as all the children from each school were evaluated during the campaign.

The Ethics Committee of the District 10D01 of the MSP supervised this study. As the anthropometric measurements and $\mathrm{Hb}$ determination were perceived to be part of the clinical evaluation of each patient, no experimentation was done during the clinical examination. All the procedures were accomplished according to national and international guidelines, to arrive at an accurate diagnosis. Apart from this, the social worker in each school also supervised this study, which was cleared as "no- risk" for the patients included in it.

\section{Body mass index}

To determine weight and height of the children in this study, the MMU personnel used the Seca 700 Physician's Balance Beam Scale with height rod and a minimum measurement of $50 \mathrm{~g}$. Using these findings, the BMI was calculated using the Quetelet index $\left[B M I=\right.$ weight $(\mathrm{Kg}) /$ height $\left.^{2}\left(\mathrm{~m}^{2}\right)\right]$. With this result, all the children were classified based on the nutrition guidelines for the primary prevention and control of overweight and obesity in children and adolescents established by the MSP, according to the WHO parameters. Using the Z-score and percentile classification, the weight, height, and BMI, were assessed for all the children included in this study. ${ }^{13,14}$ The parameters related to weight for age were as follows: (severe low weight [Z score<-3], low weight [Z score $<-2]$, normal weight and high weight); height (severe low height [Z score<-3], low height [Z score $<-2$ ], normal and high height); and BMI (severe emaciated [Z score $<-3]$, emaciated [ $Z$ score $<-2]$, overweight [Z score $>2]$ and obesity [Z score $>3]$ ]. ${ }^{15}$

\section{Hemoglobin Assessed}

The MMU nursing staff assessed the capillary $\mathrm{Hb}$ using the Mission ${ }^{\circledR} \mathrm{Hb}$ portable testing system, according to the manufacturer's manual. This system necessitates a drop of blood to be placed on the sample application area of a specific strip. Samples were obtained using 28G lancets for the required $10 \mu \mathrm{L}$ volume under conditions of asepsis and antisepsis. The puncture site was on the palmar surface at the distal phalanx of the middle finger of the left hand. The blood drop was analyzed by the equipment via a spectrophotometric system with a wavelength of $525 \mathrm{~nm}$, based on the detection principle for methemoglobin. 


\section{Hemoglobin correction}

Hemoglobin correction was established according to the $\mathrm{WHO}$ recommendations. ${ }^{16}$ consequently, the $\mathrm{Hb}$ value obtained in the Añaspamba population was reduced by $1.9 \mathrm{~g} /$ $\mathrm{dL}$. As Lita is a city located below the 1000 masl, $\mathrm{Hb}$ correction was not necessary for this patient group.

\section{Anemia diagnosis}

We used the hemoglobin values recommended by the $\mathrm{WHO}$. Children between 5 and 11 years of age were identified as having anemia if their hemoglobin level was below $115 \mathrm{~g} /$; whereas children in the age group of over 12 and up to 15 years of age were diagnosed with anemia when their hemoglobin level dropped below 120g/l.

\section{Variables}

In the present study the exposure factor was living at HA. Therefore, two patient groups were included in the study, one of which resided at the 3300-3500 masl, and the other at the 680-700 masl. In both the children groups the $\mathrm{Hb}$ value was determined, as well as the anthropometric measurements, and body mass index (BMI).

There were variables beyond the control of this study, such as ethnic differences, iron intake, poverty status, and the inclusion of a complete hematologic evaluation via hemogram and blood smear. No cases of cigarette usage or pregnancy were detected.

\section{Statistical analysis}

The clinical data were analyzed using SPSS software and Excel, both in their latest versions for Windows 10 . The risk association between living at high altitude and anemia was calculated through the odds ratio (OR). The Man-
tel-Haenszel and Breslow-Day statistical tests were used. Inhabiting high altitudes was compared with the anthropometric measurements. All the data analyzed included the confidence interval $(\mathrm{Cl})$. The linear regression method with anthropometric measurements and hemoglobin levels was employed.

\section{RESULTS}

From among a potential group of 267 patients, 228 children in all, between 5 and 15 years of age, were evaluated and categorized into two groups, based on their residential location, viz., Añaspamba and Lita. The Añaspamba group included 159 children, while the Lita group contained 69 patients. Table 1 presents

Table 1. General characteristics of the population included in this study

\begin{tabular}{l|c|c} 
& Average (SD) & Cl 95\% \\
\hline Age (years) & $10.23(2.70)$ & $9.91-10.61$ \\
Weight $(\mathrm{kg})$ & $30(9.58)$ & $28.76-31.24$ \\
Height $(\mathrm{m})$ & $1.27(0.14)$ & $1.25-1.29$ \\
\hline A & Average (SD) & Min-Max \\
\hline Hb [Anemic] (g/dl) & $10.80(0.65)$ & $9.10-11.40$ \\
Hb [Non-Anemic] (g/dl) & $12.94(0.93)$ & $11.5-16.20$ \\
\hline B & Average (SD) & Min-Max \\
\hline Hb [Anemic] (g/dl) & $10.92(0.95)$ & $7.70-11.80$ \\
Hb [Non-Anemic] (g/dl) & $13.45(1.28)$ & $12.00-16.70$ \\
Age groups & Percentage & Cl 95\% \\
5 to 6 years [n (\%)] & $17(7.69 \%)$ & $4.54-12.03$ \\
6 to 9 years [n (\%)] & $70(31.67 \%)$ & $25.60-38.25$ \\
9 to12 years [n (\%)] & $80(36.20 \%)$ & $29.86-42.91$ \\
12 to 15 years [n (\%)] & $61(24.43 \%)$ & $18.92-30.65$ \\
\hline Gender & Percentage & Cl 95\% \\
\hline Male [n (\%)] & $108(47.37 \%)$ & $40.74-54.07$ \\
Female [n (\%)] & $120(52.63 \%)$ & $45.93-59.26$ \\
\hline
\end{tabular}

SD, Standard deviation; $\mathrm{Cl}$, Confidence Interval; A, children between 5 and 11 years of age; Hb, Hemoglobin; B, children in the age group of over 12 and up to 15 years. 
the general characteristics of both groups. The general anthropometric features and $\mathrm{Hb}$ average for each group are shown in Table 2. For all the participants, the median age was 10.23 years (Cl 95\% 9.91-10.61). Besides this, the entire group revealed a similar distribution of participants among all the age groups, with the majority falling in the 9- to 12-year age group i.e., $36.20 \%$ (CI 95\% 29.86-42.91). The female children in the group formed a higher percentage, at 52.6\% (Cl 95\% 45.93-59.26). Higher values for weight, height, and BMI were observed in the group residing at the higher geographic altitude. However, the Añaspamba children in this study revealed a higher average age, with a difference of 1.1 years.

\section{Nutritional status}

A significant percentage of low height was noted among the Añaspamba (31.45\%) than the Lita $(47.83 \%)$, with average Z-scores of -2.41 (standard deviation; 0.27), and -2.54 (standard deviation; 0.25), respectively. However, $54.72 \%$ of all the low height patients among the Añas- pamba had a Z-score between -2 and -2.5. By contrast, $42.42 \%$ of the low height patients from Lita showed a Z-score value between -2 and -2.5. Furthermore, severe low height (5.66\%-7.25\%) and overweight (8.7\%-15.72\%) are frequent in both groups.

As the BMI assessment becomes inaccurate for subjects with a size less than -2.5 SD, the relationship between the height variable was calculated, taking the value of -2DS and the overweight/obesity condition (BMI Z-score > 2DS) as the cut-off point. It became clear that of the 97 low stature subjects, only one presented overweight/obesity; also, in the inferential analysis, no statistical association was demonstrated among these variables (OR 1.35; Cl 95\% 0.1215.3; $\mathrm{p}=0.42$ ).

\section{Anemia prevalence}

Anemia was found to be more frequent among the Añaspamba children group than the Lita. However no significant difference was seen on

Table 2. General characteristics of the population included in this study classified according to the groups studied

\begin{tabular}{|c|c|c|c|c|}
\hline & \multicolumn{2}{|c|}{ Añaspamba $(n=159)$} & \multicolumn{2}{|c|}{ Lita $(n=69)$} \\
\hline & Average (SD) & $\mathrm{Cl} 195 \%$ & Average (SD) & $\mathrm{Cl} 195 \%$ \\
\hline Age (years) & $10.40(2.80)$ & $9.56-10.44$ & $9.30(2.51)$ & $8.71-9.89$ \\
\hline Weight (kg) & $31.60(9.90)$ & $30.05-33.15$ & $26.20(7.59)$ & 24.41-27.99 \\
\hline Height (m) & $1.30(0.14)$ & $1.28-1.32$ & $1.22(0.12)$ & $1.18-1.24$ \\
\hline BMI & $18.13(1.43)$ & 17.91-18.35 & $17.41(2.31)$ & $16.87-17.96$ \\
\hline A & Average (SD) & Min-Max & Average (SD) & Min-Max \\
\hline $\mathrm{Hb}$ [Anemic] $(\mathrm{g} / \mathrm{dl})$ & $10.83(0.60)$ & $9.10-11.40$ & $10.58(0.97)$ & $9.50-11.40$ \\
\hline $\mathrm{Hb}$ [Non-Anemic] (g/dl) & $12.61(0.74)$ & $11.50-14.50$ & $13.38(0.99)$ & $12.00-16.20$ \\
\hline B & Average (SD) & Min-Max & Average (SD) & Min-Max \\
\hline $\mathrm{Hb}$ [Anemic] (g/dl) & 11.20 & $7.70-11.80$ & $11.20(0.54)$ & $10.40-11.50$ \\
\hline $\mathrm{Hb}$ [Non-Anemic] (g/dl) & $(0.84)$ & $12.00-16.70$ & $13.85(0.84)$ & $13.00-14.80$ \\
\hline
\end{tabular}

Masl, Meters above sea level; SD, Standard deviation; $\mathrm{Cl}$, Confidence Interval; Min-Max, Minimum and maximum values; A, children between 5 and 11 years of age; Hb, Hemoglobin; B, children in the age group of over 12 and up to 15 years. 
comparing the anthropometric variable, barring the risk of having low height linked with living in Lita. However, the Añaspamba patient group showed an additional year of age on average. The details related to anemia prevalence and risk associations, with living at high altitudes, such as the exposure factor are shown in Table 3.

Risk association between anemia and living at high altitudes

The risk association of experiencing anemia associated with the geographic altitude of residence was established (OR 2.92; CI95\% 1.29-6.59; $\mathrm{p}<0.01$ ).

Risk association between the anthropometric variables and anemia

Another finding comes from the association between the anthropometric variables (like the exposure factor) and prevalence of anemia in the patients of this study. Evidence for significant risk association was found when anemia was observed in overweight children (OR 2.92; $\mathrm{Cl} 95 \%$ 1.32-6.48; $\mathrm{p}<0.01)$. The rest of the anthropometric variables did not exert any significant effect, like the exposure factor, on the prevalence of anemia, in this analysis (Table 4).

\section{Adjusted OR for risk association between} anemia and living at $\mathrm{HA}$

Due to the significant risk association between the presence of anemia and living at $\mathrm{HA}$ and overweight, the OR was adjusted using the Mantel-Haenszel test for anemia stratification based on the BMI, with homogeneity for the OR values according to the Breslow-Day test $(p=0.63)$. Only one isolated risk association of living in $\mathrm{HA}$ for suffering anemia was found (OR 2.73 CI95\% 1.20-6.20; $p=0.01$ ).

Using the linear regression method, the variables of overweight and altitude were observed to independently and significantly affect the presence of anemia in this age group. However, the use of these two unique variables and the calculated constant are inadequate to propose a reliable predictive method, given the estimated null specificity.

\section{DISCUSION}

Anemia is the most frequently occurring disease in the developing countries and is characterized by a low $\mathrm{Hb}$ level which exerts a high impact upon the neuro-biologic development of

Table 3. Prevalence of anemia and risk associations obtained comparing the two groups included in the study having high altitude as exposure factor, Añaspamba (3300-3500 masl) and Lita (680-700 masl).

\begin{tabular}{lcc|c|c|c|} 
& Añaspamba, $\mathbf{n}(\%)$ & Lita, $\mathbf{n}(\%)$ & OR & CI 95\% & p-value \\
\hline Anemia a & $44(27.67)$ & $8(11.59)$ & 2.92 & $1.29-6.59$ & $<0.01$ \\
\hline Low weight & $10(6.29)$ & $7(10.14)$ & 0.59 & $0.22-1.63$ & 0.16 \\
Severe low weight & $1(0.63)$ & $1(1.45)$ & 0.43 & $0.03-6.98$ & 0.30 \\
\hline Low height b & $50(31.45)$ & $33(47.83)$ & 0.50 & $0.28-0.89$ & 0.01 \\
\hline Severe low height & $9(5.66)$ & $5(7.25)$ & 0.77 & $0.25-2.38$ & 0.32 \\
Overweight & $25(15.72)$ & $6(8.7)$ & 1.96 & $0.77-5.02$ & 0.08 \\
\hline Obesity & $2(1.26)$ & $0(0)$ & ND & ND & ND
\end{tabular}

Masl, Meters above sea level; OR, Odds Ratio; Cl, Confidence Interval;

a Significant value; ${ }^{\text {b }}$ Significant value, but there was a difference of 1.1 years of average ages between the groups. The percentage obtained corresponds to a total population of 159 patients in Añaspamba, and 69 patients in Lita. 
Table 4. Prevalence of anemia and risk associations obtained having nutritional status as exposure factor.

\begin{tabular}{|c|c|c|c|c|}
\hline & Total, n (\%) & Anemia, n (\%) & OR (Cl95\%) & p-value \\
\hline Low weight & $17(100)$ & $3(17.65)$ & $0.709(0.196-2.567)$ & 0.319 \\
\hline Severe low weight & $2(100)$ & $1(50)$ & $3.431(0.211-55.830)$ & 0.238 \\
\hline Low height & $83(100)$ & $18(21.69)$ & $0.904(0.473-1.729)$ & 0.386 \\
\hline Severe low height & $14(100)$ & $5(35.71)$ & $1.967(0.573-6.168)$ & 0.131 \\
\hline Overweight ${ }^{\text {a }}$ & $31(100)$ & $13(41.94)$ & $2.917(1.322-6.478)$ & 0.006 \\
\hline Obesity & $2(100)$ & $2(100)$ & ND & ND \\
\hline
\end{tabular}

OR, Odds Ratio; Cl, Confidence Interval; a Significant value; ND, Not Determined. This table includes the total of children in both groups (Añaspamba and Lita) diagnosed with Low weight, Severe low weight, Low height, Severe low height, Overweight, and Obesity. Furthermore, from these patients, we show the percentage of anemic children.

children, which significantly affected their intellectual capability and retarded their growth. ${ }^{17}$ In Latin America, the prevalence of anemia in children below 6 years of age varies from $4 \%$ in Chile to $61.3 \%$ in Bolivia, as reported in 2012 and 2008, respectively. During 2012, the prevalence of anemia in children below 6 years of age in Ecuador was considered a moderate public health problem, as was true of the other countries in that region, such as Nicaragua, Brazil, México, El Salvador, Cuba, Colombia, Dominican Republic, Perú and the Honduras. ${ }^{18}$ According to the ENSANUT-ECU 2012 (Encuesta Nacional de Salud y Nutrición-Ecuador 2012, National Health and Nutrition Survey-Ecuador 2012), the prevalence of anemia touched $25.7 \%$ in children; however, in the indigenous population, percentage reported was $41.6 \% .^{19}$ By contrast, in this study, a low prevalence of anemia was reported in both Añaspamba and Lita, compared with the reported national average. This result could be explained as this study excluded the children group below 59 months of age, a population considered to be at high risk for the prevalence of anemia. ${ }^{20}$ Besides, a study performed on the Amazon Ecuadorian children reveals $16.6 \%$ prevalence of anemia, in a group which includes patients between 5 and 14 years of age, bearing similarity to the results of the present study. ${ }^{21}$ This data requires verification through studies which should necessarily include more number of patients and rural communities. It is important to consider the lack of data regarding the prevalence of anemia and malnutrition in Ecuadorian children, in the context of ethnic differences, as well as the different nutritional habits of each population.

The main finding from this study is the risk association of anemia with living in HA. These findings could correspond with a report showing the prevalence of anemia being higher than expected in the Andean children population, as well as comments that the prevalence of anemia shows variations from up to $76 \%$ in Puno (Andes region) down to a $34 \%$ minimum in La Libertad (coastal area), in Peru. However, these results could be due to the influence of the geographic location, economic status, and nutritional determinants, besides the quality of access to health services. ${ }^{22} \mathrm{~A}$ study performed in La Paz, Bolivia, shows the prevalence of anemia at $22 \%, 31 \%$ and $15 \%$ respectively, in the Camacho, Ingaví, and Murillo provinces, located at similar geographic altitudes as the Añaspamba, somewhat in accordance with our finding. ${ }^{23}$ Not corresponding to our results, an investigation via three national nutrition surveys fails to show any difference in the prevalence of anemia in children or adolescents, among 
the different geographic regions in Mexico. ${ }^{24}$ On the other hand, a publication based on data drawn from women of childbearing age reveals a change in the prevalence of anemia when the $\mathrm{Hb}$ is corrected based on the geographic altitude, with dramatic results, ranging from $2.5 \%$ without correction to $28.8 \%$ with correction, at 3000-4000 m above sea level. ${ }^{25}$ This report is crucial because there is a possibility that the lack of correction in the $\mathrm{Hb}$ values at $\mathrm{HA}$ could affect the results of the prevalence of anemia in people living in different geographic altitudes. It is therefore vital that these results be clarified, in order to improve the health of the population living at HA by prevention. In light of this fact, one study reported that children with anemia at $\mathrm{HA}$ are at greater risk for poor outcomes when they are treated for severe pneumonia (RR 4.07; Cl 95\% 2.60-6.38). ${ }^{26}$ Therefore, any effort taken to reduce the prevalence of anemia could also decrease malnutrition in the children, as well as minimize the incidence of infectious disease. Besides the risk association between living at high altitudes and anemia, this study shows how two populations in the same administrative region have different degrees of prevalence of anemia in children; this could prove to be a point of reference for the epidemiological investigation, to enhance and encourage the well-directed use of the public health resources. The biological explanation for the findings in this study is beyond the methodology employed in this study. However, one of the possible reasons is the association that could exist between the high EPO level present and a deficient iron intake in the rural communities located at HA.

EPO is a hormone which controls the heme production by triggering the genes responsible for heme metabolism, including ferrochelatase $(\mathrm{FECH})$. This enzyme is essential for the inclusion of ferrous iron into the molecule called protoporphyrin IX, in the mitochondria of the early erythroid cells, with hypoxia being one of the most important determinants for raising the EPO levels. ${ }^{27}$ Iron deficiency was cited to cause EPO hypo-responsiveness, ${ }^{28}$ a fact that could be significant considering the high EPO levels in the Andean population and the manner in which an excess of this hormone could trigger the production of nonhealthy erythroid cells in the absence of an adequate iron supplementation. ${ }^{29}$ Nevertheless, it is vital that new studies realize the impact exerted by high erythropoietin levels on iron-deficient patients, mainly in the Andean population.

Another finding presented in this study, is the association between anemia and obesity, an observation made earlier in another study $(p<0.05)$, which suggests the importance of evaluating iron metabolism in obese children, similar to the findings in the current study..$^{30}$ This finding could be explained as being caused by the adipose tissue with its inflammatory characteristics; subsequently such a tissue type could induce the hepcidin and $C$ reactive protein levels to rise, both of which are linked to iron metabolism.

Some significant limitations are present in this study; the main one being that only a few patients and two rural schools were involved. This is one reason why result should be used carefully. In this context, we recommend further investigations in different communities and also increase the number of patients in this kind of studies to obtain more significant and generalizable outcomes. Similarly, we cannot include in our variables studied the poverty index of each population, as well as we cannot explain if the ethnic difference is a determinant in our findings. Furthermore, there wasn't a complete investigation on iron metabolism for each patient, or even a complete blood count (CBC). We recommend for further research the detailed blood analysis through $\mathrm{CBC}$ in addition to iron metabolism evaluation. Also, it would be interesting to understand in detail the possible hypo responsiveness of bone 
marrow to erythropoietin in malnutrition and iron deficiency, and also to describe how this condition could affect the progression of other pathologies.

In conclusion, the findings obtained in this study shows living in $\mathrm{HA}$ as a potential risk factor for suffering anemia, something that indicates how iron deficiency could have a different impact on a diverse population. However, these findings should be replicated in larger populations, and through a detailed hematological evaluation, and also, considering the ethnic and nutritional differences. It's important to remark the association described between overweight and anemia. These results might have a significant impact on public health and also in general physicians and pediatricians during the medical evaluation to improve the management of children in risk of anemia.

\section{REFERENCES}

1. Ortega PA, Leal JY, Chávez CJ, Mejías L, Chirinos N, Escalona $C$. Anemia and iron depleted reserves in pregnant adolescents from urban and rural area, Zulia state, Venezuela. Rev Chil Nutr. 2012;39(3):11-17.

2. Vásquez E. La anemia en la infancia. Pan Am J Public Health. 2003;13(6):349-351.

3. Batra J, Sood A. Iron deficiency anaemia: Effect on cognitive development in children: A review. Indian J Clin Biochem. 2005;20(2):119-125.

4. Prentice AM, Mendoza YA, Pereira D, Cerami C, Wegmuller $\mathrm{R}$, Constable $A$, et al. Dietary strategies for improving iron status: balancing safety and efficacy. Nutr Rev. 2017;75(1):49-60.

5. Sánchez-Llaguno S, Neira-Mosquera JA, Pérez-Rodríguez F, Moreno R. Preliminary nutritional assessment of the Ecuadorian diet based on a 24-h food recall survey in Ecuador. Nutr Hosp. 2013; 28:1646-1656.

6. Ochoa-Avilés A, Verstraeten R, Lachat $C$, Andrade S, Van Camp J, Donoso $S$, et al. Dietary intake practices associated with cardiovascular risk in urban and rural Ecuadorian adolescents: a cross-sectional study. BMC Public Health. 2014; 14:939.

7. Alli N, Vaughan J, Patel M. Anaemia: Approach to diagnosis. S Afr Med J. 2017;107(1):23-27.

8. Loza J, Dulanto A, Paz-Marchena A, Málaga G, Ticse R. Differences in anemia detection in high altitude according to the World Health Organization. Rev Peru Med Exp Salud Publica. 2012; 29:157-8.
9. Cook JD, Boy E, Flowers C, Daroca M. The influence of highaltitude living on body iron. Blood. 2005; 106:1441-1446.

10. Beall CM, Brittenham GM, Strohl KP, Blangero J, Blangero SW, Goldstein MC, et al. Hemoglobin Concentration of High-Altitude Tibetans and Bolivian Aymara. Am. J. Phys. Anthropol. 1998;106:385-400.

11. Basu M, Malhotra AS, Pal K, Prasad R, Kumar R, Prasad $B A$, et al. Erythropoietin levels in lowlanders and highaltitude natives at $3450 \mathrm{~m}$. Aviat Space Environ Med. 2007;78(10):963-7.

12. Madore F, Lowrie EG, Brugnara C, Lew NL, Lazarus JM, Bridges $\mathrm{K}$, Owen WF. Anemia in hemodialysis patients: variables affecting this outcome predictor. J Am Soc Nephrol. 1997;8(12):1921-9.

13. Kassebaum NJ, Jasrasaria R, Naghavi M, Wulf SK, Jons N, Lozano $R$, et al. A systematic analysis of global anemia burden from 1990 to 2010. Blood. 2014;123(5):615-624.

14. Torres-Tamayo M, Aguilar-Herrera BE, Altamirano-Bustamante N, Barquera S, Barrientos-Pérez M, Bracho-Blanchet $E$, et al. Consenso de expertos sobre prevención, diagnóstico y tratamiento de la obesidad en edad pediátrica. Bol Med Hosp Infant Mex. 2015;72(1):1-28.

15. salud.gob.ec. Unidad de Nutrición, Guías y Manuales. [Internet]. Ecuador: Ministerio de Salud Pública del Ecuador; c2017 [cited 2017 Jul 10]. Available from: http://www.salud. gob.ec/unidad-de-nutricion-guias-y-manuales/

16. who.int. Concentraciones de hemoglobina para diagnosticar la anemia y evaluar su gravedad. [Internet]. Ginebra: Organización Mundial de la Salud; c2017 [cited 2017 Jul 16]. Available from: http://www.who.int/vmnis/indicators/ haemoglobin_es.pdf

17. Pasillas-Torres EM, Rodríguez-Ortega EE. Childhood anemia in Mexico: A public health problem at all socioeconomic levels. Bol Med Hosp Infant Mex 2014; 71:95-102.

18. Mujica-Coopman MF, Brito A, López de Romaña D, RíosCastillo I, Cori H, Olivares M. Prevalence of Anemia in Latin America and the Caribbean. Food and Nutrition Bulletin. 2015;36(2): S119-S12.

19. Freire WB, Ramírez-Luzuriaga MJ, Belmont P, Mendieta MJ, Silva-Jaramillo MK, Romero N, et al. Tomo I: Encuesta Nacional de Salud y Nutrición de la población ecuatoriana de cero a 59 años. ENSANUT-ECU 2012. Ministerio de Salud Pública/ Instituto Nacional de Estadísticas y Censos 2014. 41-429.

20. Segarra J, Lasso S, Chacón K, Segarra M, Huiracocha L. Estudio Transversal: Desnutrición, Anemia y su Relación con Factores Asociados en Niños de 6 a 59 Meses, Cuenca 2015. Rev Med HJCA. 2016; 8(3): 231-237.

21. Quizhpe E, San Sebastian M, Hurtig AK, Llamas A. Prevalencia de anemia en escolares de la zona amazónica de Ecuador. Rev Panam Salud Publica/Pan Am J Public Health. 2003;3(6):355-361

22. Amerson R, Miller L, Glatt M, Ramsey K, Baker J. Assessment of Anemia Levels in Infants and Children in High Altitude Peru. Glob J Health Sci. 2017;9(7):87-95. 
23. Miranda M, Olivares M, Durán-Pérez J, Pizarro F. Prevalencia de anemia y estado nutricional de escolares del área periurbana de Sucre, Bolivia. Rev chil nutr. 2015; 42(4):324-327.

24. De la Cruz-Góngora V, Villalpando S, Mundo-Rosas V, Shamah-Levy T. Prevalencia de anemia en niños y adolescentes mexicanos: comparativo de tres encuestas nacionales. Salud Pública Méx. 2013;55(2): s180-s189.

25. Loza J, Dulanto A, Paz-Marchena A, Málaga G, Ticse R. Differences in anemia detection in high altitude according to the World Health Organization [Letter]. Rev Peru Med Exp Salud Publica. 2012;29(1):157-158.

26. Moschovis PP, Banajeh S, MacLeod WB, Saha S, Hayden D, Christiani DC, et al. Childhood Anemia at High Altitude:
Risk Factors for Poor Outcomes in Severe Pneumonia. Pediatrics. 2013;132(5): e1156-e1162.

27. Fried W. Erythropoietin and erythropoiesis. Exp Hematol. 2009;37(9):1007-1015.

28. Locatelli F, Andrulli S, Memoli B, Maffei C, Del Vecchio L, Aterini $S$, et al. Nutritional-inflammation status and resistance to erythropoietin therapy in haemodialysis patients. Nephrol Dial Transplant. 2006;21(4):991-998.

29. Beall CM. Two routes to functional adaptation: Tibetan and Andean high-altitude natives. Proc Natl Acad Sci U S A. $2007 ; 104(1): 8655-8660$.

30. Ghadimi R, Esmaili H, Kheirkhah D, Tamaddoni A. Is Childhood Obesity Associated with Iron Deficiency Anemia? Caspian J of Pediatr. 2015;1(2):59-66.

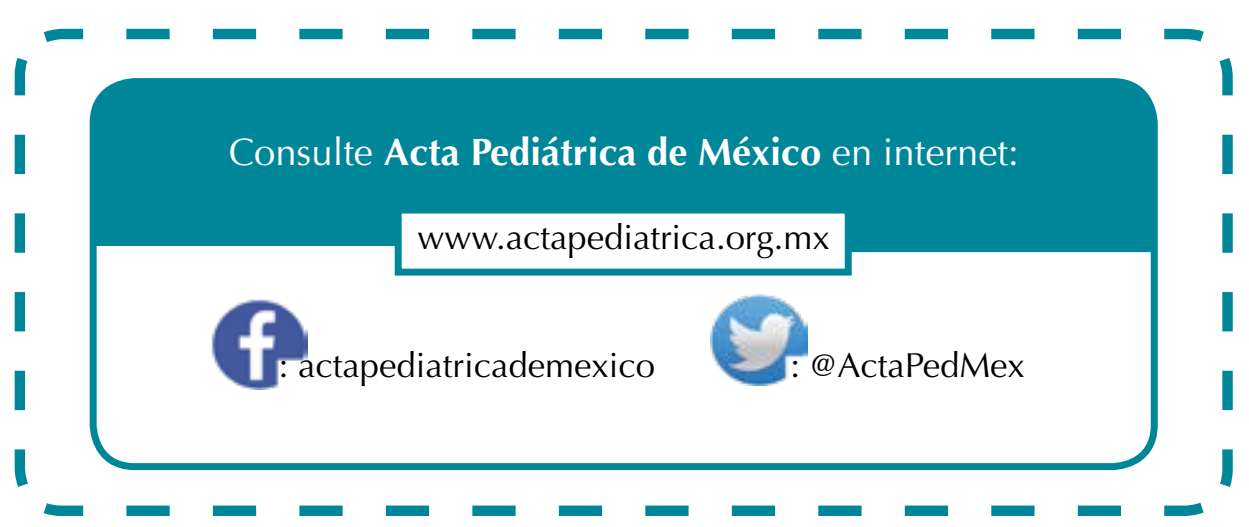

